\title{
PENERAPAN STRATEGI JURNAL KATA DALAM MENINGKATKAN KETERAMPILAN MENEMUKAN GAGASAN UTAMA DI KELAS V SD
}

\author{
Ersila Devy Rinjani \\ Dosen FAI Unwahas Semarang \\ ersiladevy28@gmail.com
}

\begin{abstract}
Abstrak
Salah satu tujuan pembelajaran Bahasa Indonesia adalah agar peserta didik memiliki kemampuan berkomunikasi secara efektif dan efisien sesuai dengan eti-ka yang berlaku, baik secara lisan maupun tulis. Namun, faktanya pembelajaran Bahasa Indonesia di kelas V SDN Kalibanteng Kidul 01 kurang menggunakan strategi pembelajaran yang kreatif, sehingga dengan keterampilan guru yang kurang berdampak pada keaktivan dan hasil belajar bahasa Indonesia peserta didik yang rendah. Penelitian ini berupaya untuk melihat penerapan strategi jurnal kata dalam meningkatkan keterampilan guru, aktivitas, dan hasil belajar peserta didik. Penelitian dilaksanakan dalam tiga siklus, masing-masing siklus satu kali pertemuan. Teknik pengumpulan data menggunakan tes, observasi, wawancara, angket, dokumentasi, dan catatan lapangan. Teknik analisis data yang digunakan adalah secara deskriptif kuantitatif dan deskriptif kualitatif. Adapun hasil penelitian menunjukan adanya peningkatan keterampilan guru, aktivitas peserta didik, dan hasil belajar pada kualitas pembelajaran Bahasa Indonesia khususnya keterampilan menemukan gagasan utama dengan strategi jurnal kata di setiap siklusnya.
\end{abstract}

Kata kunci: keterampilan menemukan gagasan utama, jurnal kata 


\begin{abstract}
One of the goals of learning Indonesian is that learners have the ability to communicate effectively and efficiently in accordance with the applicable ethic, both orally and writing. However, the fact that Indonesian language learning in class $V$ of SDN Kalibanteng Kidul 01 is less in using creative learning strategies, so with the less teacher skill causes the activity and the result of Indonesia language study by students are low. This study is to understand about applying word journal strategy for increasing teacher skill, students activity, and study result of students. This study was conducted at tree cycles, each cycle once meeting. Data collection techniques are use tests, observations, interviews, questionnaires, documentation, and field notes. The data analysis techniques used are descriptive quantitative and descriptive qualitative. These results indicate an increase in the teacher's skill, student activities, and learning outcomes in the quality of the Indonesian language learning in particular on the skills of finding the main ideas using Word Journal strategy each cycles.
\end{abstract}

Keywords: skills of finding the main idea, Word Journal

\title{
A. Pendahuluan
}

Setiap kelompok mata pelajaran memiliki kualifikasi masing-masing yang diatur pada standar isi. Peraturan Menteri Pendidikan Nasional Nomor 22 Tahun 2006 tentang Standar Isi untuk satuan pendidikan dasar dan menengah bahwa standar kompetensi Bahasa Indonesia merupakan kualifikasi kemampuan minimal peserta didik yang menggambarkan penguasaan, pengetahuan, keterampilan berbahasa, dan sikap positif terhadap bahasa dan sastra Indonesia. Pembelajaran Bahasa Indonesia diarahkan untuk meningkatkan kemampuan peserta didik dalam berkomunikasi melalui Bahasa Indonesia secara benar, baik lisan maupun tulis, serta menumbuhkan apresiasi terhadap hasil karya kesastraan manusia Indonesia.

Mata pelajaran Bahasa Indonesia perlu diberikan kepada peserta didik, khususnya pada tingkat pendidikan sekolah dasar, karena kemampuan 
berbahasa anak merupakan landasan bagi anak dalam mempelajari mata pelajaran lain. Pembelajaran bahasa diharapkan membantu anak dalam mengenal dirinya, budayanya, budaya orang lain, membantu dalam pengungkapan gagasan dan perasaan serta menggunakan bahasa tersebut dalam berpartisipasi di masyarakat. ${ }^{1}$

Proses pembelajaran Bahasa Indonesia sangat identik dengan empat keterampilan proses yaitu; menyimak, berbicara, membaca, dan menulis, yang dikemas dalam pembelajaran yang terpadu. Walaupun keempat aspek keterampilan itu dikemas dalam pembelajaran yang terpadu, guru dapat memfokuskan ke dalam satu bagian materi pengajaran aspek keterampilan tersebut. Berdasarkan temuan Pusat Kurikulum dalam praktiknya pembelajaran Bahasa Indonesia di SD, guru belum menggunakan pembelajaran yang kreatif, variatif, dan terampil, serta kurang mengoptimalkan media pembelajaran. Peserta didik cenderung menjadi bosan, lebih pasif, dan keterampilan dalam menyimak dan menyerap informasi menjadi lemah atau dapat dikatakan peserta didik kurang termotivasi. $^{2}$

Berdasarkan hasil survei tersebut, seharusnya membaca menjadi perhatian khusus dalam proses pembelajaran di sekolah khususnya dalam menemukan gagasan utama. Hal itu pula yang seharusnya diperhatikan di kelas V SDN Kalibanteng Kidul 01. Berdasarkan refleksi awal tim kolaborasi, pembelajaran Bahasa Indonesia pada aspek keterampilan menemukan gagasan utama belum optimal. Fakta menunjukan guru belum menerapkan strategi pembelajaran yang kreatif. Hasil data dokumen dan evaluasi pada peserta didik kelas V SDN Kalibanteng Kidul 01, ada 21 peserta didik yang mengalami ketidaktuntasan pada nilai rata-rata ulangan harian dengan KKM 71. Data hasil belajar ditunjukan dengan nilai terendah 62 dan nilai tertinggi

1 BNSP, Panduan Penyusunan Kurikulum Tingkat Satuan Pendidikan Jenjang Pendidikan Dasar dan Menengah, (Jakarta: Depdiknas, 2006), hlm. 119.

2 Pusat Kurikulum, Naskah Akademik Kajian Kebijakan Kurikulum Mata Pelajaran Bahasa, (Jakarta: Depdiknas, 2007), hlm. 9. 
93, serta memiliki nilai rata-rata kelas yaitu 72,97, dengan ketuntasan peserta didik pada nilai rata-rata ulangan harian Bahasa Indonesia mencapai persentase 44,73\% (17 peserta didik), sedangkan ketidaktuntasan peserta didik pada nilai rata-rata ulangan harian Bahasa Indonesia memiliki persentase yang lebih tinggi, yakni 55,26\% (21 peserta didik).

Berdasarkan data hasil belajar dan pelaksanaan mata pelajaran bahasa Indo-nesia, peneliti dan kolaborator sepakat untuk melakukan pengkajian melalui pe-nelitian tindakan kelas dengan menggunakan strategi pembelajaran yang sesuai dengan kondisi kelas dan mampu untuk menutupi segala kekurangan yang terjadi dalam kegiatan pembelajaran. Strategi pembelajaran yang diharapkan mampu meningkatkan keterampilan guru dan aktivitas peserta didik yang berdampak pada hasil belajar adalah dengan menerapkan strategi jurnal pada pembelajaran. Pembelajaran dengan strategi jurnal adalah suatu praktik penulisan atau pencatatan pada sebuah kertas tentang kumpulan pemikiran, pemahaman, dan penjelasan, tentang sebuah gagasan atau konsep. ${ }^{3}$

Strategi jurnal ini menaungi strategi jurnal belajar. Silberman mengatakan jurnal belajar adalah catatan reflektif atau diari yang dibuat oleh peserta didik dari hari ke hari. Ketika peserta didik diminta menulis suatu jurnal mengenai pengalaman belajar dan refleksi diri, guru dapat membantu peserta didik untuk mendapatkan yang terbaik dari proses pembelajaran. ${ }^{4}$ Jurnal belajar juga memberikan suatu pandangan yang mendalam tentang cara berpikir peserta didik dan menolong peserta didik untuk memonitor pemahaman mereka secara pribadi. ${ }^{5}$

Berdasarkan pembelajaran jurnal yang terfokus pada strategi jurnal belajar, peneliti memfokuskan kembali pada jurnal kata, jurnal kata termasuk

3 Warsono dan Haryanto, Pembelajaran Aktif Teori dan Asesmen, (Bandung: Rosda Karya, 2012), hlm. 38

4 Silbermen, Melvin L., Strategi Pembelajaran Berorientasi Standar Proses Pendidikan, Terjemahan Raisul Muttaqien, (Jakarta: Nuansa, 2012), hlm. 205.

5 Wormeli, Rick., Meringkas Mata Pelajaran, Terjemahan Trinardi Linoto, (Jakarta: Erlangga, 2011), hlm. 117. 
pengembangan dari jurnal belajar. Peneliti memilih strategi jurnal kata karena kaitannya dengan pembelajaran Bahasa Indonesia dan pembangunan konsep belajar peserta didik berdasarkan argumen peserta didik. Strategi jurnal kata menurut pendapat Zaini, dkk. adalah strategi yang memiliki dua tugas, yaitu pertama, ringkasan dalam satu kata atau frase yang di ambil dari wacana; kedua, argumen peserta didik dalam memilih kata atau frase itu. Semua argumen harus merujuk ke wacana. Jurnal satu kata adalah sinopsis dari sebuah wacana. 6

Berdasarkan latar belakang tersebut maka rumusan masalah pada penelitian ini adalah "bagaimanakah jurnal kata dapat meningkatkan keterampilan guru, aktivitas, dan hasil belajar peserta didik pada keterampilan menemukan gagasan utama di kelas V SDN Kalibanteng Kidul 01?". Tujuan penelitian ini adalah meningkatkan kualitas pembelajaran Bahasa Indonesia kelas V SDN Kalibanteng Kidul 01, yang meliputi keterampilan guru, aktivitas, dan hasil belajar peserta didik pada keterampilan menemukan gagasan utama.

\section{B. Landasan Teori}

\section{Gagasan Utama}

Paragraf berperan sebagai sumber informasi. Berdasarkan pendapat Akhadiah, Sabarti., Maidar G. Arsjad, dan Sakura h. Ridwan, pengertian paragraf adalah penuangan buah pikiran dalam sebuah karangan. Paragraf mengandung ide yang didukung oleh kalimat pengenal, kalimat utama, kalimat penjelas, dan kalimat penutup, serta saling berhubungan dalam membentuk sebuah gagasan. ${ }^{7}$ Doyin dan Wagiran berpendapat paragraf adalah merupakan perpaduan kalimat yang membicarakan suatu gagasan atau topik. Paragraf juga merupakan

${ }^{6}$ Zaini, Hisyam,. Bermawy Munthe, Sekar Ayu Aryani, Strategi Pembelajaran Aktif, (Jogjakarta: Pustaka Insan Madani, 2008), hlm. 165-166.

${ }^{7}$ Zaini, Hisyam,. Bermawy Munthe, Sekar Ayu Aryani, Strategi..., hlm. 144. 
kumpulan kalimat yang memiliki satu pikiran saling berkalitan membentuk gagasan. Topik-topik paragraf adalah pikiran utama pada paragraf. 8

Berdasarkan pendapat ahli, dapat disimpulkan bahwa paragraf adalah buah pikiran yang diwujudkan dalam serangkaian kalimat yang membentuk suatu gagasan tertentu. Kalimat-kalimat pada sebuah paragraf saling berkaitan membentuk sebuah gagasan atau pokok pembahasan. Paragraf terdiri atas kalimat utama dan kalimat penjelas yang saling terkait. Gagasan utama sebagai pusat dari pembicaraan yang dibahas pada paragraf, hal tersebut terlihat pada jenis paragraf deduktif, induktif, dan campuran. Gagasan utama pada paragraf deduktif terletak pada awal paragraf, sedangkan gagasan utama pada paragraf induktif terletak pada akhir paragraf, dan gagasan utama pada paragraf campuran terletak pada awal dan akhir paragraf. Gagasan utama dapat disebut juga sebagai bahasan secara umum dari suatu paragraf.

Menurut Nurhadi prosedur membaca paragraf untuk mengetahui gagasan utama adalah sebagai berikut:

1) Telitilah kalimat pertama, mungkin mengandung gagasan utama;

2) Jika prosedur pertama bukan, telitilah dengan cermat kalimat terakhir;

3) Jika prosedur kedua bukan, teliti keseluruhan paragraf, dan cari fakta-faktanya;

4) Perhatikan secara cermat kata-kata yang tercetak tebal, bergaris bawah, atau tercetak miring. ${ }^{9}$

Berdasarkan pendapat ahli, dapat disimpulkan bahwa gagasan utama merupakan pikiran utama dari sebuah paragraf. Gagasan utama merupakan gambaran secara umum dari pembahasan pada sebuah paragraf, gambaran umum ini didukung dengan adanya kalimat penjelas yang bersifat khusus. Semua pembicaraan dalam paragraf tersebut 27.

8 Doyin Mukh dan Wagiran, Bahasa Indonesia, (Semarang: Nusa Budaya, 2002), hlm. 107-108.

9 Nurhadi, Membaca Cepat dan Efektif, (Bandung: Sinar Baru Algensindo, 2008), hlm. 
berpusat pada gagasan utama. Gagasan utama itulah yang menjadi pokok pembicaraan. Cara dalam menemukan gagasan utama adalah dengan memperhatikan bentuk paragraf yang dibaca serta memperhatikan dengan cermat kata-kata yang tercetak tebal, bergaris bawah, dan tercetak miring.

\section{Strategi Jurnal Kata}

Strategi jurnal kata menginduk pada teknik pembelajaran jurnal harian. Menurut pendapat Hariyanto \& Warsono, pembelajaran dengan jurnal adalah praktik penulisan atau pencatatan pada sebuah kertas tentang kumpulan pemikiran, pemahaman, dan penjelasan tentang sebuah gagasan atau konsep. Guru dapat menggunakan jurnal tersebut sebagai tolak ukur seberapa pahamkah anak-anak memahami bahan ajar yang telah mereka pelajari. Kegiatan ini merupakan kegiatan memindahkan pemikiran, gagasan, dan perasaan para peserta didik. ${ }^{10}$

Selain menginduk pada teknik pembelajaran jurnal, strategi jurnal kata juga merupakan suatu pengembangan dari strategi jurnal belajar. Silberman menyatakan jurnal belajar adalah sebuah catatan reflektif atau diari yang dibuat oleh peserta didik dari hari ke hari. Strategi ini sesuai untuk digunakan apabila peserta didik diminta untuk mencatat pengalaman-pengalaman belajar mereka dan mengungkapkan apa yang mereka pahami secara tertulis melalui sebuah catatan. ${ }^{11}$ Berdasarkan pembelajaran jurnal yang terfokus pada strategi jurnal belajar, peneliti memfokuskan kembali pada jurnal kata, jurnal kata termasuk pengembangan dari jurnal belajar. Peneliti memilih strategi jurnal kata karena kaitannya dengan pembelajaran Bahasa Indonesia dan pembangunan konsep belajar berdasarkan argumen peserta didik.

\footnotetext{
10 Warsono dan Haryanto, Pembelajaran Aktif Teori dan Asesmen, (Bandung: Rosda Karya, 2012), hlm. 38.

11 Silbermen, Melvin L., Strategi Pembelajaran Berorientasi Standar Proses Pendidikan, Terjemahan Raisul Muttaqien, (Jakarta: Nuansa, 2012), hlm. 205
} 
Zaini, dkk. mengatakan jurnal kata adalah strategi yang memiliki dua tugas sekaligus; pertama, ringkasan dalam satu kata atau frase yang dibuat dari sebuah wacana. Kedua, argumen dalam satu atau dua paragraf mengapa memilih atau membuat kata atau frase itu. Semua argumen mutlak menunjuk ke wacana tersebut. Jurnal satu kata adalah satu abstraksi atau sinopsis dari sebuah wacana. Langkah-langkah strategi jurnal kata adalah sebagai berikut.

1) Pilihlah satu teks wacana singkat sebagai bahan asesmen;

2) Mintalah peserta didik membaca teks itu dengan cermat;

3) Kemudian, tugaskan peserta didik untuk memilih satu kata atau satu frase yang paling penting atau menarik dari teks wacana itu;

4) Mungkin juga Anda menentukan fokus dari teks wacana yang akan dipelajari oleh peserta didik, apakah:

(1) Tema utama;

(2) Pusat konflik;

(3) Tren ;

(4) Dan lain-lain.

5) Selanjutnya, mintalah kembali peserta didik memberikan keterangan atau argumen tentang pemilihan kata atau frase itu;

6) Tegaskan kepada peserta didik bahwa pemilihan kata tertentu dari teks wacana adalah kurang penting dari pada kualitas argumen atau keterangan;

7) Informasikan kepada peserta didik bahwa pemilihan kata atau frase harus berhubungan dengan pemilihan kata atau frase;

8) Setelah peserta didik mengerjakan tugas, Anda mengumpulkannya dan siap untuk melakukan koreksi atau evaluasinya dengan kriteria yang sudah dibuat; 
9) Setelah dikoreksi, Anda mengembalikannya kepada peserta didik atau peserta didik. ${ }^{12}$

Berdasarkan langkah-langkah pembelajaran strategi jurnal kata menurut Zaini,dkk., peneliti mengembangkan langkah-langkah pembelajaran yang diterap-kan pada keterampilan menemukan gagasan utama dengan menerapkan strategi jurnal kata. Langkah-langkah pembelajarannya adalah sebagai berikut.

1) Guru memberi teks wacana singkat pada peserta didik;

2) Peserta didik membaca teks wacana secara cermat;

3) Peserta didik diminta untuk memilih kata atau frase penting dalam paragraf atau wacana tersebut;

4) Guru menentukan fokus dari teks wacana yang akan dipelajari oleh peserta didik, dalam hal ini adalah gagasan utama;

5) Peserta didik diminta untuk memberikan argumen tentang pemilihan kata atau frasa tersebut;

6) Guru menginformasikan kepada peserta didik bahwa pemilihan kata harus sesuai dengan isi wacana;

7) Peserta didik diminta untuk menentukan gagasan utama dari katakata yang telah dipilih;

8) Guru mengoreksi atau mengevaluasi;

9) Pengembalian hasil pekerjaan peserta didik.

Berdasarkan pendapat ahli mengenai jurnal kata maka dapat disimpulkan strategi jurnal kata merupakan strategi yang memiliki dua tugas sekaligus, yaitu menuntut anak dalam memilih kata kunci dan menjelaskan secara tertulis apa alasan mereka dalam menentukan kata kunci tersebut. Kaitannya dengan keterampilan menentukan gagasan utama adalah selain menentukan kata kunci dan argumen mereka, anak-

12 Zaini, Hisyam,. Bermawy Munthe, Sekar Ayu Aryani, Strategi Pembelajaran Aktif, (Jogjakarta: Pustaka Insan Madani, 2008), hlm. 165-166. 
anak diminta untuk mengembangkan kata kunci tersebut menjadi sebuah gagasan utama berdasarkan isi paragraf pada bacaan yang mereka baca. Jurnal kata sebagai strategi menekankan pada proses pelaksanaan ju rnal kata sesuai dengan sintaknya yang memuat proses langkah-langkahnya secara urut. Penerapan strategi jurnal kata diharapkan peserta didik dapat terampil dalam pengungkapan argumen atau penadapat mereka mengenai suatu kasus tertentu, selain itu anak akan terampil dalam mengembangkan gagasan utama pada suatu paragraf berdasarkan kata kunci yang mereka temukan sendiri dengan kata-kata mereka sendiri pula.

\section{Penelitian yang Relevan}

Penelitian ini didasarkan pada hasil penilitian yang telah dilakukan sebelumnya terhadap pembelajaran Bahasa Indonesia tentang keterampilan menemukan gagasan utama dan strategi yang setara dengan jurnal kata. Berikut pemaparan hasil penelitian yang relevan.

Penelitian Eke O. Uduma tahun 2011 dengan judul Journal Keeping in an ESL Classroom: an Innovative Approach in Language Learning, penelitian ini me-nyatakan journal keeping adalah sebuah proses pedagogis untuk membentuk tulisan yang dihubungkan dengan keterampilan membaca. Jurnal memungkinkan peserta didik untuk fokus pada ekspresi pemikiran dan ide-ide mereka yang dituliskan pada kertas. Journal keeping sukses diterapkan pada kelas ESL karena adanya kerjasama dan pemahaman antara peserta didik dan guru. ${ }^{13}$

Penelitian Yenny Anjar Jayandi tahun 2008 dengan judul Penggunaan Jurnal Belajar dengan Macromedia Flash dalam Pembelajaran Biologi untuk Meningkatkan Kualitas Pembelajaran Peserta didik Kelas X di SMA Negeri 2 Surakarta. Penerapan penggunaan jurnal belajar pada pembelajaran biologi

13 Uduma Eke O., Journal Keeping in an ESL Classroom: an Innovative Approach in Language Learning, 2011, Jurnal Internasional www.iiste.org diakses pada tanggal 16 Januari 2013 pukul 10.00 
dengan media macromedia flash bisa meningkatkan kualitas pembelajaran yang dapat dilihat dari peningkatan motivasi belajar dan partisipasi peserta didik yang berdampak pada peningkatan penguasaan konsep. ${ }^{14}$

Penelitian Bambang Kustriadi tahun 2011 dengan judul Menggunakan Stra-tegi Learning Log untuk Memperbaiki Keterampilan Menulis dalam Bahasa Inggris Peserta didik Kelas Dua MTs Wachid Hasyim Surabaya. Hasil penelitian menunjukan bahwa strategi learning log dapat memperbaiki kemampuan menulis peserta didik dalam bahasa Inggris. Perbaikan keterampilan itu dapat dilihat dari hasil tulisan baik dari kuantitas dan kualitas. Juga bisa dilihat dari hasil skor akhir peserta didik. ${ }^{15}$

Penelitian-penelitian yang telah dilakukan sebelumnya menjadi dasar refrensi atas penelitian ini. Penelitian yang hendak dilakukan sebagai pelengkap dari penelitian yang lain, karena penerapan strategi jurnal khususnya strategi jurnal kata belum pernah diterapkan pada mata pelajaran Bahasa Indonesia khususnya di sekolah dasar. Sehingga penelitian ini juga dapat menjadi refrensi bagi guru sebagai upaya meningkatkan kualitas belajar dan menjadi refrensi bagi peneliti-peneliti lain.

\section{Kerangka Berpikir}

Berdasarkan refleksi awal tim kolaborasi, pembelajaran Bahasa Indonesia pada aspek keterampilan menemukan gagasan utama masih belum optimal, gagasan utama peserta didik masih belum sesuai dengan isi bacaan. Supaya hasil belajar peserta didik pada mata pelajaran Bahasa Indonesia dapat meningkat, peneliti berkolaborasi dengan guru kelas V memberikan solusi berupa penggunaan strategi jurnal kata. Pada pembelajaran yang menerapkan srategi jurnal kata, guru memberikan kesempatan kepada

14 Jayandi, Yenny Anjar, Penggunaan Jurnal Belajar dengan Macromedia Flash dalam Pembelajaran Biologi untuk Meningkatkan Kualitas Pembelajaran Siswa Kelas X di SMA Negeri 2 Surakarta,2008, Jurnal pada biologi.fkip.uns.ac.id diakses pada tanggal 24 Desember 2012 pukul 23:30

15 Kustriadi Bambang, Menggunakan Stra-tegi Learning Log untuk Memperbaiki Keterampilan Menulis dalam Bahasa Inggris Siswa Kelas Dua MTs Wachid Hasyim Surabaya, 2011, karya-ilmiah-.um.ac.id diakses pada tanggal 24 Desember 2012 pukul 23:30 
peserta didik untuk dapat mengembangkan keterampilan berbahasa, potensi diri, dan wawasan dalam belajar. Pembelajaran lebih interaktif jika ada peran aktif peserta didik yang didukung dengan keterampilan guru untuk menciptakan suasana belajar yang kondusif dan menyenangkan. Lebih jelasnya alur kerangka berpikir berdasarkan uraian tersebut dapat dilihat pada gambar berikut. 


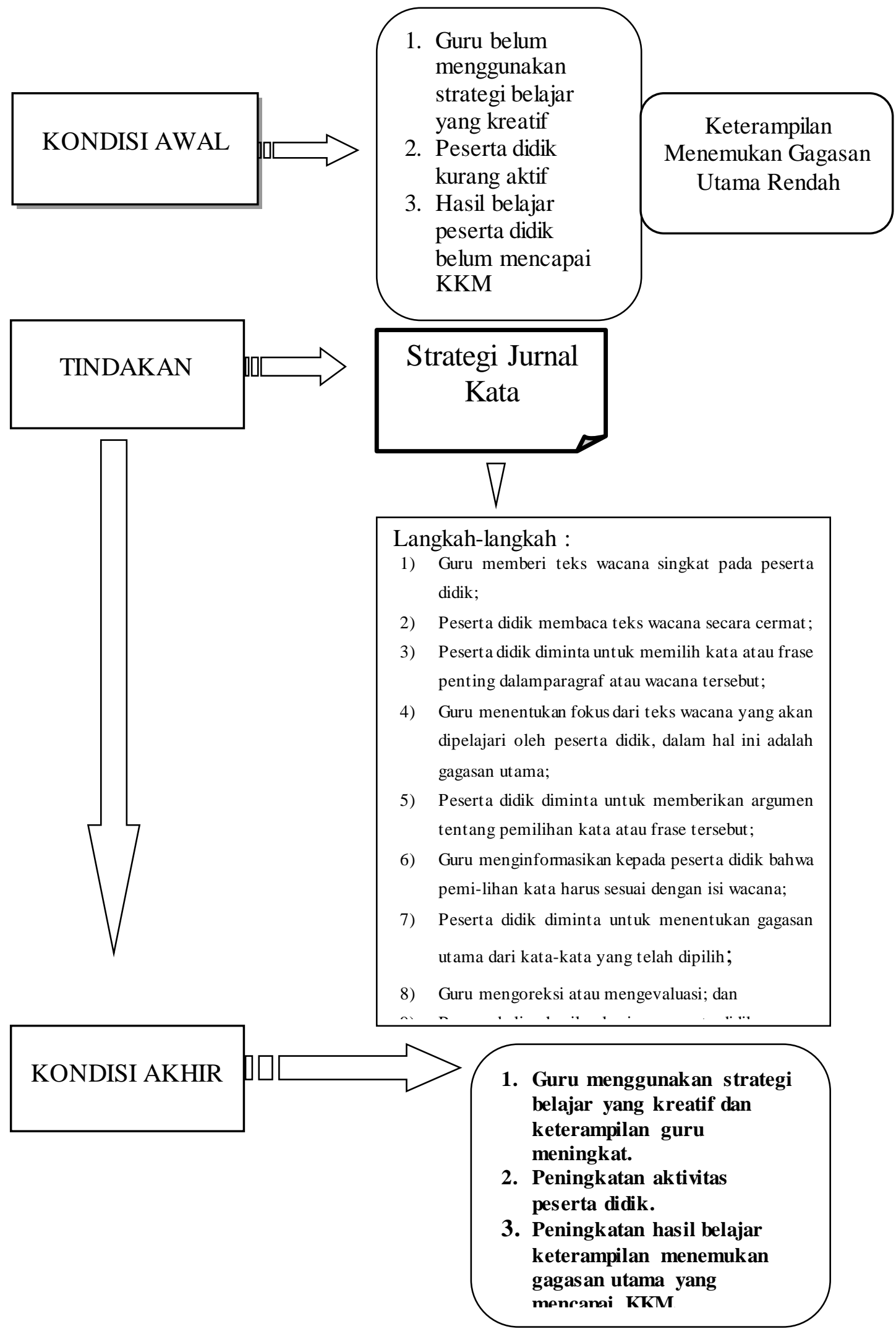

Bagan 1. Kerangka Berpikir 


\section{E. Hipotesis Tindakan}

Berdasarkan uraian pada kajian pustaka dan kerangka berpikir di atas, maka hipotesis tindakan penelitian ini adalah dengan menggunakan strategi jurnal kata, kualitas pembelajaran Bahasa Indonesia pada peserta didik kelas V SDN Kalibanteng Kidul 01 dapat meningkat.

\section{F. Metode Penelitian}

Penelitian kolaboratif ini dilakukan di SDN Kalibanteng Kidul 01, Kecamatan Semarang Barat, Kotamadya Semarang dengan subyek penelitian adalah peserta didik kelas $\mathrm{V}$ sebanyak 39 peserta didik yang terdiri atas 21 peserta didik laki-laki dan 18 perempuan, serta guru di kelas tersebut. Penelitian ini merupakan penelitian tindakan kelas. Berdasarkan pendapat Arikunto, dkk., penelitian tindakan kelas merupakan tindakan terhadap kegiatan belajar yang sengaja dan terjadi dalam kelas secara bersama-sama. Tindakan tersebut diberikan oleh guru atau dengan arahan guru yang dilakukan oleh peserta didik. ${ }^{16}$ Berdasarkan pendapat Kunandar, pada penelitian tindakan kelas terdapat empat aspek pokok yaitu penyusunan rencana, tindakan, observasi, dan refleksi. Keempat kegiatan tersebut dilaksanakan dalam tiga siklus pertemuan. ${ }^{17}$

Peneliti melakukan pengumpulan data dengan menggunakan teknik tes dan non tes. Teknik non tes meliputi observasi, wawancara, angket, studi dokumentasi, dan catatan lapangan. Observasi dalam penelitian ini digunakan untuk menggambarkan aktivitas peserta didik dan keterampilan guru dalam pembelajaran Bahasa Indonesia mengenai keterampilan menemukan gagasan utama. Wawancara ditujukan pada guru untuk mengetahui bagaimana pendapat guru tentang pembelajaran Bahasa Indonesia mengenai keterampilan menemukan gagasan utama dengan

\footnotetext{
16 Arikunto, Suharsimi, dkk., Penelitian Tindakan Kelas, (Jakarta: Bumi Aksara, 2009),
} hlm. 3. $71-75$

17 Kunandar, Penelitian Tindakan Kelas, (Jakarta: Rajagrafindo Persada, 2011), hlm. 
strategi jurnal kata yang dilakukan oleh peneliti. Metode angket digunakan untuk mengetahui pendapat peserta didik terhadap kualitas pembelajaran Bahasa Indonesia dalam menemukan gagasan utama dengan jurnal kata. Penggambaran secara konkret mengenai kegiatan kelompok peserta didik dan penggambarkan suasana kelas ketika aktivitas belajar berlangsung digunakan dokumen berupa foto. Catatan lapangan digunakan untuk merefleksi proses pembelajaran yang telah berlangsung yang menggambarkan proses pembelajaran, keterampilan guru, dan aktivitas peserta didik.

Teknik analisis data yang digunakan adalah analisis kuantitatif dan kualitatif. Analisis data kuantitatif pada setiap siklusnya dilakukan dengan cara memberikan evaluasi berupa soal tes tertulis pada setiap akhir siklusnya. Ada dua kategori ketuntasan, yaitu secara perseorangan dan klasikal. Peserta didik dikatakan berhasil dan tuntas dalam pembelajaran Bahasa Indonesia pada keterampilan menemukan gagagsan utama bila nilai hasil belajar peserta didik telah mencapai $\geq 71$. Data hasil pengamatan dari lembar pengamatan keterampilan guru dan aktivitas peserta didik dianalisis menggunakan teknik deskriptif kualitatif yang digambarkan dengan kalimatkalimat.

\section{G. Hasil Penelitian}

\section{Hasil Penelitian Siklus I}

Deskripsi data hasil observasi keterampilan guru menunjukan delapan indikator keterampilan guru masuk dalam kategori baik, tiga indikator masuk dalam kategori sangat baik, dan dua indikator masuk dalam kategori kurang. Indikator yang masuk dalam kategori kurang diantaranya keterampilan mengelola kelas dan keterampilan memberi penguatan. Secara keseluruhan hasil observasi keterampilan guru memperoleh skor 38 dengan kualifikasi baik. 
Deskripsi data hasil observasi aktivitas peserta didik menunjukan enam indikator aktivitas peserta didik masuk dalam kategori cukup dan empat indikator masuk dalam kategori aktif. Indikator yang masuk dalam kategori aktif adalah kesiapan dalam belajar, membaca teks wacana, menyimpulkan hasil pembelajaran, dan menyelesaikan evaluasi. Secara keseluruhan hasil observasi aktivitas peserta didik memperoleh skor 25,94 dengan kualifikasi cukup.

Persentase ketuntasan hasil belajar peserta didik pada siklus pertama sebesar 59\% dari indikator keberhasilan yang ditentukan 75\%. Peserta didik yang belum tuntas pada siklus pertama sebesar 41\%, sehingga persentase hasil belajar peserta didik pada siklus pertama belum memenuhi indikator keberhasilan dan perlu ditingkatkan pada siklus kedua.

\section{Hasil Penelitian Siklus II}

Deskripsi data hasil observasi keterampilan guru menunjukan empat indikator keterampilan guru masuk dalam kategori baik dan sembilan indikator masuk dalam kategori sangat baik. Indikator yang masuk dalam kategori baik diantaranya keterampilan menyampaikan tujuan pembelajaran, menjelaskan materi kepada peserta didik, melakukan tanya jawab kepada peserta didik, dan melakukan refleksi pembelajaran. Secara keseluruhan hasil observasi keterampilan guru memperoleh skor 48 dengan kualifikasi sangat baik.

Deskripsi data hasil observasi aktivitas peserta didik menunjukan kesepuluh indikator aktivitas peserta didik masuk dalam kategori aktif. Secara keseluruhan hasil observasi aktivitas peserta didik memperoleh skor 31,12 dengan kualifikasi aktif. Persentase ketuntasan hasil belajar peserta didik pada siklus kedua meningkat menjadi 65\% dari indikator keberhasilan yang ditentukan $75 \%$. Peserta didik yang belum tuntas pada siklus kedua sebesar 35\%, sehingga persentase hasil belajar peserta didik 
pada siklus kedua masih belum memenuhi indikator keberhasilan dan perlu ditingkatkan pada siklus ketiga.

\section{Hasil Penelitian Siklus III}

Deskripsi data hasil observasi keterampilan guru pada siklus ketiga menunjukan tiga indikator keterampilan guru masuk dalam kategori baik dan sepuluh indikator masuk dalam kategori sangat baik. Indikator yang masuk dalam kategori baik diantaranya keterampilan guru dalam melaksanakan pengondisisan kelas, melakukan penguatan terhadap presesntasi kelompok, dan melakukan reflek-si pembelajaran. Secara keseluruhan hasil observasi keterampilan guru memperoleh skor 49 dengan kualifikasi sangat baik.

Deskripsi data hasil observasi aktivitas peserta didik menunjukan lima indikator aktivitas peserta didik masuk dalam kategori aktif dan lima indikator yang lain masuk dalam kategori sangat aktif. Kelima indikator yang telah masuk dalam kategori sangat aktif adalah aktivitas peserta didik dalam kesiapan belajar, membaca teks wacana, memberikan tanggapan terhadap hasil karya/laporan kelompok lain, menyimpulkan hasil pembelajaran, dan menyelesaikan evaluasi. Secara keseluruhan hasil observasi aktivitas peserta didik memperoleh skor 34,23 dengan kategori sangat aktif.

Persentase ketuntasan hasil belajar peserta didik pada siklus kedua meningkat menjadi 76\% dari indikator keberhasilan yang ditentukan 75\%. Peserta didik yang belum tuntas pada siklus ketiga sebesar 23\%. Berdasarkan persentase ketuntasan yang mencapai 76\%, maka hasil belajar peserta didik pada siklus ketiga telah melibihi dari indikator keberhasilan yang ditentukan yaitu 75\%.

\section{H. Pembahasan}

Indikator keterampilan guru dalam meningkatkan keterampilan menemukan gagasan utama dengan jurnal kata adalah (1) melaksanakan 
pengondisian kelas; (2) menyampaikan tujuan pembelajaran; (3) melakukan apersepsi sesuai dengan materi; (4) memilih media pembelajaran yang relevan; (5) menjelaskan materi kepada peserta didik; (6) membentuk peserta didik ke dalam kelompok; (7) menyajikan wacana untuk dianalisis peserta didik; (8) membimbing penyelidikan kelompok; (9) melakukan tanya jawab kepada peserta didik; (10) memberikan kesempatan semua kelompok untuk menyajikan hasil karya/laporan; (11) memberikan penguatan terhadap presentasi kelompok; (12) melakukan refleksi pembelajaran; (13) memberikan evaluasi dan tindak lanjut.

Keterampilan dasar mengajar merupakan seperangkat keterampilan dalam proses pembelajaran yang dilakukan guru dari awal hingga akhir pembelajaran. Pembelajaran yang efektif sangat tergantung dari penguasaan keterampilan ini. Bedasarkan pendapat Anitah dkk., keterampilan dasar guru bersifat generik, artinya perlu dikuasai oleh semua guru. Pemahaman dan kemampuan menerapkan keterampilan dasar yang baik, guru diharapkan mampu meningkatkan kualitas pembelajaran. Menurut hasil penelitian Turney (dalam Anitah W., dkk.), terdapat 8 keterampilan dasar mengajar yang harus dikuasai oleh guru, yaitu keterampilan bertanya, memberi penguatan, mengadakan variasi, menjelaskan, membuka dan menutup pelajaran, membimbing diskusi kelompok kecil, mengelola kelas, mengajar kelompok kecil dan perorangan. ${ }^{18}$

Indikator aktivitas peserta didik dalam meningkatkan keterampilan menemukan gagasan utama dengan jurnal kata adalah sebagai berikut (1) kesiapan dalam belajar; (2) memperhatikan penjelasan guru tentang materi paragraph dan gagasan utama; (3) membaca teks wacana; (4) memilih kata atau frase dari paragraf; (5) memberikan argumen; (6) membuat hasil karya/menentukan gagasan pokok;(7) mempresentasikan hasil karya;(8) memberikan tanggapan terhadap hasil karya/laporan kelompok lain; (9) menyimpulkan hasil pembelajaran; (10) menyelesaikan evaluasi. Kesepuluh 18 Anitah W. Sri, dkk., Strategi Pembelajaran di SD, (Jakarta: Universitas Terbuka,
2009), hlm. 83 
aktivitas peserta didik yang diteliti sudah menunjukkan atau menggambarkan kedelapan aktivitas peserta didik menurut Dierich. Dierich (dalam Hamalik) berpendapat aktivitas peserta didik dalam pembelajaran digolongkan menjadi aktivitas visual, aktivitas lisan, aktivitas mendengarkan, aktivitas menulis, aktivitas menggambar, aktivitas metrik, aktivitas mental, dan aktivitas emosional. ${ }^{19}$

Hasil belajar peserta didik pada keterampilan menentukan gagasan utama dengan jurnal kata mengalami peningkatan pada siklus 1 sampai dengan siklus 3. Penilaian hasil belajar sebaiknya mencakup tiga ranah, yaitu ranah kognitif, afektif, dan psikomotorik. Penilaian hasil belajar terkait erat dengan tujuan belajar, pada umumnya tujuan pembelajaran mengikuti pengklasifikasian dari hasil belajar. Teori Bloom menurut Anderson (dalam Rusman 2012), menyatakan hasil belajar mencakup tiga ranah yaitu kognitif, afektif, dan psikomotorik. Keterampilan guru yang baik maka akan mempengaruhi aktivitas peserta didik. Dengan demikian keterampilan guru dan aktivitas peserta didik dalam pembelajaran akan berpengaruh terhadap hasil belajar, khususnya terhadap gagasan utama pada pembelajaran bahasa Indonesia.

\section{Simpulan}

Berdasarkan hasil penelitian dan pembahasan yang telah dilaksanakan mengenai peningkatan keterampilan menemukan gaggasan utama dengan jurnal kata pada peserta didik kelas V SDN Kalibanteng Kidul 01 dapat disimpulkan beberapa hal sebagai berikut.

1. Keterampilan guru pada keterampilan menemukan gagasan utama dengan jurnal kata meningkat dengan hasil observasi pada siklus pertama sebesar 38 dengan kuali-fikasi baik, siklus kedua sebesar 48 dengan kualifikasi sangat baik, dan siklus ketiga sebesar 49 dengan kualifikasi sangat baik. Berdasarkan hasil observasi setiap siklus tersebut, $172-173$

19 Oemar Hamalik, Proses Belajar Mengajar, (Bandung: Bumi Aksara, 2005), hlm. 
menandakan bahwa strategi jurnal kata dapat meningkatkan keterampilan guru pada keterampilan menemukan gagasan utama.

2. Aktivitas peserta didik pada keterampilan menemukan gagasan utama dengan jurnal kata meningkat dengan hasil observasi pada siklus pertama sebesar 25,94 dengan kualifikasi cukup, siklus kedua sebesar 31,12 dengan kualifikasi aktif, dan siklus ke-tiga sebesar 34,23 dengan kualifikasi aktif. Berdasarkan hasil observasi setiap siklus tersebut, menandakan bahwa strategi jurnal kata dapat meningkatkan aktivitas peserta didik pada keterampilan menemukan gagasan utama.

3. Hasil belajar peserta didik pada keterampilan menemukan gagasan utama dengan jurnal kata meningkat dengan hasil observasi pada siklus pertama sebesar 59\% peserta didik tuntas dengan rata-rata kelas 70,25, siklus kedua sebesar $65 \%$ peserta didik tuntas dengan rata-rata kelas 78,97, dan siklus ketiga sebesar 76\% peserta didik tuntas dengan rata-rata kelas 81,28. Berdasarkan hasil observasi setiap siklus tersebut, menandakan bahwa strategi jurnal kata dapat meningkatkan hasil belajar peserta didik pada keterampilan menemukan gagasan utama. 


\section{DAFTAR PUSTAKA}

Anitah W. Sri, dkk., Strategi Pembelajaran di SD, Jakarta: Universitas Terbuka, 2009

Arikunto, Suharsimi, dkk., Penelitian Tindakan Kelas, Jakarta: Bumi Aksara, 2009

Bambang, Kustriadi, Menggunakan Stra-tegi Learning Log untuk Memperbaiki Keterampilan Menulis dalam Bahasa Inggris Siswa Kelas Dua MTs Wachid Hasyim Surabaya, 2011, karya-ilmiah-.um.ac.id diakses pada tanggal 24 Desember 2012 pukul 23:30

BNSP, Panduan Penyusunan Kurikulum Tingkat Satuan Pendidikan Jenjang Pendidikan Dasar dan Menengah, Jakarta: Depdiknas, 2006

Doyin Mukh dan Wagiran, Bahasa Indonesia, Semarang: Nusa Budaya, 2002

Jayandi, Yenny Anjar, Penggunaan Jurnal Belajar dengan Macromedia Flash dalam Pembelajaran Biologi untuk Meningkatkan Kualitas Pembelajaran Siswa Kelas X di SMA Negeri 2 Surakarta,2008, Jurnal pada biologi.fkip.uns.ac.id diakses pada tanggal 24 Desember 2012 pukul 23:30

Kunandar, Penelitian Tindakan Kelas, Jakarta: Rajagrafindo Persada, 2011

Nurhadi, Membaca Cepat dan Efektif, Bandung: Sinar Baru Algensindo, 2008

Oemar Hamalik, Proses Belajar Mengajar, Bandung: Bumi Aksara, 2005

Pusat Kurikulum, Naskah Akademik Kajian Kebijakan Kurikulum Mata Pelajaran Bahasa, Jakarta: Depdiknas, 2007

Silbermen, Melvin L., Strategi Pembelajaran Berorientasi Standar Proses Pendidikan, Terjemahan Raisul Muttaqien, Jakarta: Nuansa, 2012

Silbermen, Melvin L., Strategi Pembelajaran Berorientasi Standar Proses Pendidikan, Terjemahan Raisul Muttaqien, Jakarta: Nuansa, 2012

Uduma Eke 0., Journal Keeping in an ESL Classroom: an Innovative Approach in Language Learning, 2011, Jurnal Internasional www.iiste.org diakses pada tanggal 16 Januari 2013 pukul 10.00

Warsono dan Haryanto, Pembelajaran Aktif Teori dan Asesmen, Bandung: Rosda Karya, 2012 
Warsono dan Haryanto, Pembelajaran Aktif Teori dan Asesmen, Bandung: Rosda Karya, 2012

Wormeli, Rick., Meringkas Mata Pelajaran, Terjemahan Trinardi Linoto, Jakarta: Erlangga, 2011

Zaini, Hisyam,. Bermawy Munthe, Sekar Ayu Aryani, Strategi Pembelajaran Aktif, Jogjakarta: Pustaka Insan Madani, 2008

Zaini, Hisyam,. Bermawy Munthe, Sekar Ayu Aryani, Strategi Pembelajaran Aktif, Jogjakarta: Pustaka Insan Madani, 2008 